Special issue of the 2nd International Conference on Computational and Experimental Science and Engineering (ICCESEN 2015)

\title{
Effect of Heavy Metals and Antibiotics on Siderophores Producing Bacterial Isolates
}

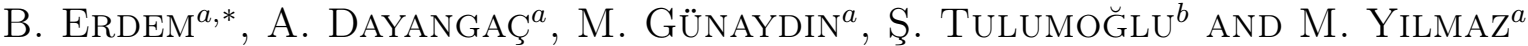 \\ ${ }^{a}$ Ahi Evran University, Department of Biology, Kırşehir, Turkey \\ ${ }^{b}$ Doctor Behçet Uz Hospital for Child Diseases Education and Research, Microbiology Laboratory, Izmir, Turkey \\ In this study, siderophore-producing bacterial species have been isolated from soils contaminated with diesel \\ oil. In $P$. aeruginosa (P-7) production of siderophores was inhibited at concentrations of $\mathrm{ZnSO}_{4}$ and $\mathrm{CoCl}_{2}$ of \\ $2000 \mu \mathrm{M}$, while $B$. subtilis (BS-1) has increased siderophores production at similar concentrations of $\mathrm{CoCl}_{2}$ and \\ $\mathrm{ZnSO}_{4}$. The same bacteria have increased the production of siderophores in presence of streptomycine $(512 \mathrm{mg} / \mathrm{ml})$. \\ In $B$. subtilis the production of siderophores was inhibited by cefuroxime. The results show the effect of met- \\ als on the efficiency of siderophore production by bacteria for potential application in bioremediation of metal- \\ contaminated iron-deficient soils in the microbial assisted phytoremediation processes. The results include the effect \\ of metals on siderophore production efficiency of the bacteria used for the bioremediation of metal-contaminated \\ soils. In conclusion, it has been found that heavy metals and antibiotics significantly effect the production of \\ siderophores by bacteria.
}

DOI: 10.12693/APhysPolA.130.181

PACS/topics: 87.85.J-, 92.20.jb, 95.75.Fg

\section{Introduction}

Siderophores, iron-binding ligands, are produced by microorganisms under conditions in which the amount of iron is limited [1]. Many other metals and amino acids were found to suppress or stimulate siderophore production in bacteria $[2,3]$. Effect of metals on the efficiency of siderophore production by bacteria is essential for potential applications in bioremediation of metal-contaminated iron-deficient soils, especially in the microbe-assisted phytoremediation processes [4]. Metalresistant siderophore-producing bacteria play an important role in the successful survival and growth of plants in metal-contaminated soils [5]. During our studies on siderophore-producing bacteria from the soil contaminated with diesel oil we have investigated the influences of heavy metals $\left(\mathrm{CoCl}_{2}\right.$ and $\left.\mathrm{ZnSO}_{4}\right)$ and antibiotics (cefuroxime and streptomycine) on siderophore production.

\section{Materials and methods}

\subsection{Isolation and identification of the isolate}

The bacterial strain, used in this study, was isolated from soils contaminated with diesel oil. The selected isolates $P$. aeruginosa (P-7) and B. subtilis (BS-1) were grown on nutrient agar and their cultural, morphological and biochemical characteristics were observed.

\subsection{Screening for siderophore production}

The production of siderophore by the isolates was detected using chrome azurol sulphonate (CAS) assay, as reported by Schwyn and Neiland [6], in iron-free succinic acid medium consisting of $6.0 \mathrm{~g} / 1$ of $\mathrm{K}_{2} \mathrm{HPO} 4$,

\footnotetext{
* corresponding author; e-mail: berdem@ahievran.edu.tr
}

$3.0 \mathrm{~g} / \mathrm{l}$ of $\mathrm{KH}_{2} \mathrm{PO} 4,0.2 \mathrm{~g} / \mathrm{l}$ of $\mathrm{MgSO}_{4} \cdot 7 \mathrm{H}_{2} \mathrm{O}, 1.0 \mathrm{~g} / \mathrm{l}$ of $\mathrm{NH}_{4} \mathrm{SO}_{4}$, and $4.0 \mathrm{~g} / \mathrm{l}$ of succinic acid, at $28^{\circ} \mathrm{C}$ under constant shaking at $120 \mathrm{rpm}$ for $24-48 \mathrm{~h} \mathrm{[7].} \mathrm{After}$ the incubation, cell density was measured at $640 \mathrm{~nm}$ by using double-beam UV-visible spectrophotometer (Shimadzu 1240, Japan).

\subsection{Determination of minimal inhibitory concentrations}

$P$. aeruginosa and B. subtilis $\left(6 \times 10^{7}\right.$ cells $\left./ \mathrm{ml}\right)$ were grown in succinate medium externally supplemented with $700-2000 \mu \mathrm{M}$ of compounds of heavy metals like $\mathrm{CoCl}_{2}$ and $\mathrm{ZnSO}_{4}$ at $28^{\circ} \mathrm{C}$ at $120 \mathrm{rpm}[8]$ and with cefuroxime and streptomycine $(32,64,128,256$ and $512 \mathrm{mg} / \mathrm{ml})$. We have studied the influence of different concentrations of bacterial growth inhibitors on siderophores production in succinate medium. The strains were grown in succinate medium with different concentrations of the following inhibitors: $\mathrm{CoCl}_{2}, \mathrm{ZnSO}_{4}$, cefuroxime and streptomycine.

\section{Results and discussion}

\subsection{Siderophore production and detection}

Change in color of CAS agar and CAS reagent from blue to orange-red indicated the ability of $P$. aeruginosa and $B$. subtilis to produce and excrete siderophores. Detection of siderophores and the change in color of the CAS reagent was due to the fact that siderophores, present in the supernatant, chelate the iron from the CAS reagent, which results in color change from blue to orange-red [9].

\subsection{Minimal inhibitory concentration of metal and antibiotics}

The results indicate that $P$. aeruginosa shows resistance compared to other bacteria as reported by Rachid 
and Bensoltane [10] and by Filali et al. [11]. Minimal inhibitory concentrations of the two antibiotics and tested metal salts are shown in Tables I and II. The results indicate that these strains show resistance compared to other bacteria, as reported by Filali et al. [11]. Strain P-7 was found to be the most resistant strain to the metals and antibiotics. B. subtilis has exhibited resistance to cefuroxime, while the same bacteria were sensitive to streptomycine. Among all preparations, the broth rich in siderophores exhibited potent antibacterial activity. The minimum bactericidal concentration of siderophore was $2000 \mu \mathrm{M}$ for both $P$. aeruginosa and B. subtilis.

\subsection{Effect of metals and antibiotics on bacterial siderophore production}

Significant increase in extracellular siderophore production by $B$. subtilis was observed in the presence of $\mathrm{CoCl}_{2}$ and $\mathrm{ZnSO}_{4}$ at concentrations of $2000 \mu \mathrm{M}$ (Table I), whereas in the present study the $P$. aeruginosa (P-7) have shown no siderophore production at concentrations of $2000 \mu \mathrm{M}$ (Fig. 1).
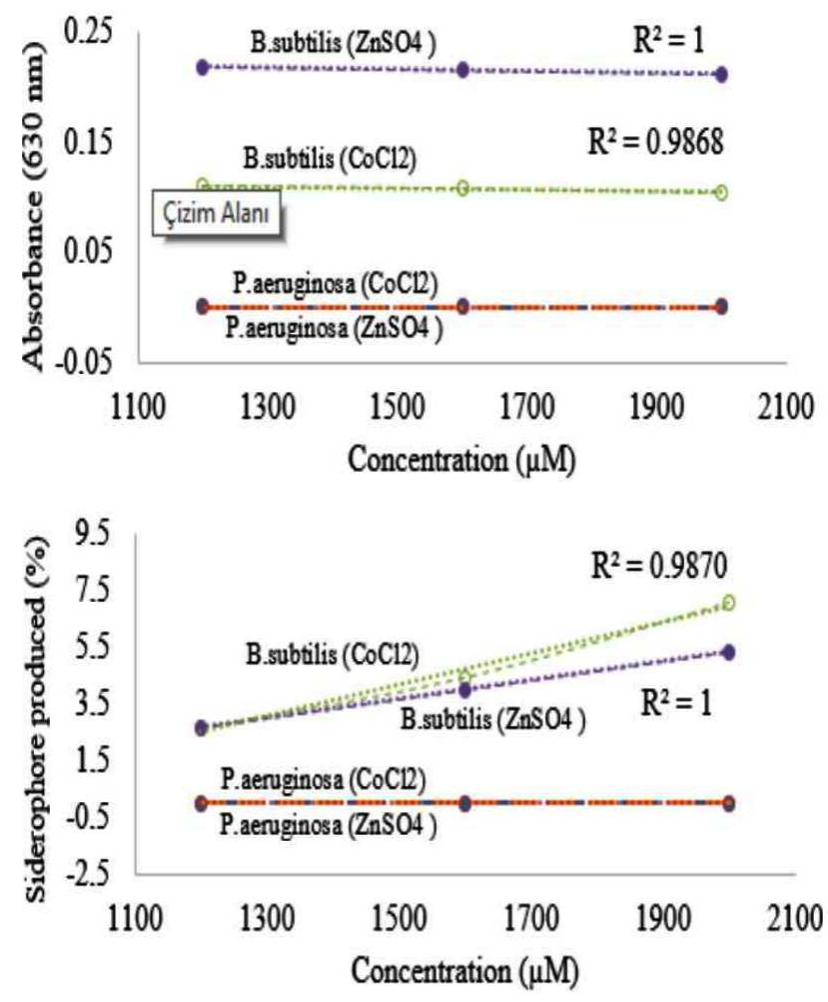

Fig. 1. Effect of $\mathrm{CoCl}_{2}$ and $\mathrm{ZnSO}_{4}$ on siderophore production in succinate medium by $P$. aeruginosa and B. subtilis.

The value of regression $R^{2}$ of the relationship between the concentrations of $\mathrm{CoCl}_{2}$ and $\mathrm{ZnSO}_{4}$ and the concentration of the produced siderophore was found to be higher for the UV spectroscopic method (Table I). Figure 1 shows that there exists a linear relationship between the applied concentrations of $\mathrm{CoCl}_{2}$ and $\mathrm{ZnSO}_{4}$ and the concentration of the produced siderophore.
TABLE I

Effect of $\mathrm{CoCl}_{2}$ and $\mathrm{ZnSO}_{4}$ on siderophore production in succinate medium by $B$. subtilis (BS-1).

\begin{tabular}{|c|c|c|c|c|c|}
\hline $\begin{array}{c}\text { Metal } \\
\text { ions } \\
{[\mu \mathrm{M}]} \\
\end{array}$ & $\begin{array}{c}\text { Absorbance } \\
\text { at } 630 \mathrm{~nm}\end{array}$ & $R^{2}$ & $\begin{array}{l}\text { Reference } \\
\text { at } 630 \mathrm{~nm}\end{array}$ & $\begin{array}{c}\text { \% Siderophore } \\
\text { produced } \\
{[\mu \mathrm{g} / \mathrm{ml}]}\end{array}$ & $R^{2}$ \\
\hline \multicolumn{6}{|c|}{$\mathrm{CoCl}_{2}[\mu \mathrm{M}]$} \\
\hline 1200 & 0.110 & \multirow{3}{*}{0.9868} & 0.113 & 2.65 & \multirow{3}{*}{0.9870} \\
\hline 1600 & 0.108 & & 0.113 & 4.42 & \\
\hline 2000 & 0.105 & & 0.113 & 7.07 & \\
\hline \multicolumn{6}{|c|}{$\mathrm{ZnSO}_{4}[\mu \mathrm{M}]$} \\
\hline 1200 & 0.218 & \multirow{3}{*}{1} & 0.224 & 2.67 & \multirow{3}{*}{1} \\
\hline 1600 & 0.215 & & 0.224 & 4.01 & \\
\hline 2000 & 0.212 & & 0.224 & 5.35 & \\
\hline
\end{tabular}

An increase of siderophore production was observed in B.subtilis at concentrations of $\mathrm{CoCl}_{2}$ and $\mathrm{ZnSO}_{4}$ of $2000 \mu \mathrm{M} . \mathrm{ZnSO}_{4}$ as well as $\mathrm{CoCl}_{2}$ are known to bind to siderophores and have shown a $2.67 \%$ and $5.35 \%$ decrease in growth at 1600 and $2000 \mu \mathrm{M}$ respectively, which was suppressed at lower concentrations of 1200 and $1600 \mu \mathrm{M}$ (Fig. 1).

Streptomycine has inhibited siderophore production in $P$. aeruginosa (Table II).

TABLE II

Effect of cefuroxime and streptomycine on siderophore production in succinate medium by B. subtilis (BS-1).

\begin{tabular}{|c|c|c|c|c|c|}
\hline $\begin{array}{c}\text { Antibiotics } \\
{[\mathrm{mg} / \mathrm{ml}]}\end{array}$ & $\begin{array}{l}\text { Absorbance } \\
\text { at } 630 \mathrm{~nm}\end{array}$ & $\begin{array}{c}R^{2} \\
\text { value }\end{array}$ & $\begin{array}{c}\text { Reference } \\
\text { at } \\
630 \mathrm{~nm}\end{array}$ & $\begin{array}{c}\% \text { Siderophore } \\
\text { produced } \\
{[\mu \mathrm{g} / \mathrm{ml}]}\end{array}$ & $\begin{array}{c}R^{2} \\
\text { value }\end{array}$ \\
\hline \multicolumn{6}{|c|}{ Cefuroxime $[\mathrm{mg} / \mathrm{ml}]$} \\
\hline 128 & 0.00 & \multirow{3}{*}{-} & 0.115 & 0.00 & \multirow{3}{*}{-} \\
\hline 256 & 0.00 & & 0.115 & 0.00 & \\
\hline 512 & 0.00 & & 0.115 & 0.00 & \\
\hline \multicolumn{6}{|c|}{ Streptomycine $[\mathrm{mg} / \mathrm{ml}]$} \\
\hline \begin{tabular}{l|}
128 \\
\end{tabular} & 0.095 & \multirow{3}{*}{0.9842} & 0.113 & 15.9 & \multirow{3}{*}{0.9846} \\
\hline 256 & 0.091 & & 0.113 & 19.4 & \\
\hline 512 & 0.086 & & 0.113 & 23.8 & \\
\hline
\end{tabular}

A significant positive correlation was found between concentrations, measured using UV spectroscopic method, of the the streptomycine and siderophores produced by B.subtilis (Table II).

While streptomycine has increased the production of siderophores in B.subtilis, siderophore production was inhibited by cefuroxime (Fig. 2).

Metal-resistant siderophore-producing bacteria play an important role in the successful survival and growth of plants in contaminated soils by alleviating the metal toxicity and supplying the plant with nutrients, particularly with iron [12]. P. aeruginosa JAS-25 has the potential to act as an excellent biocontrol agent against phytopathogens of agricultural crops [13]. Siderophores from strain Bacillus sp SD12 pave the way for their utilization in the field of medicine and agriculture [14]. 

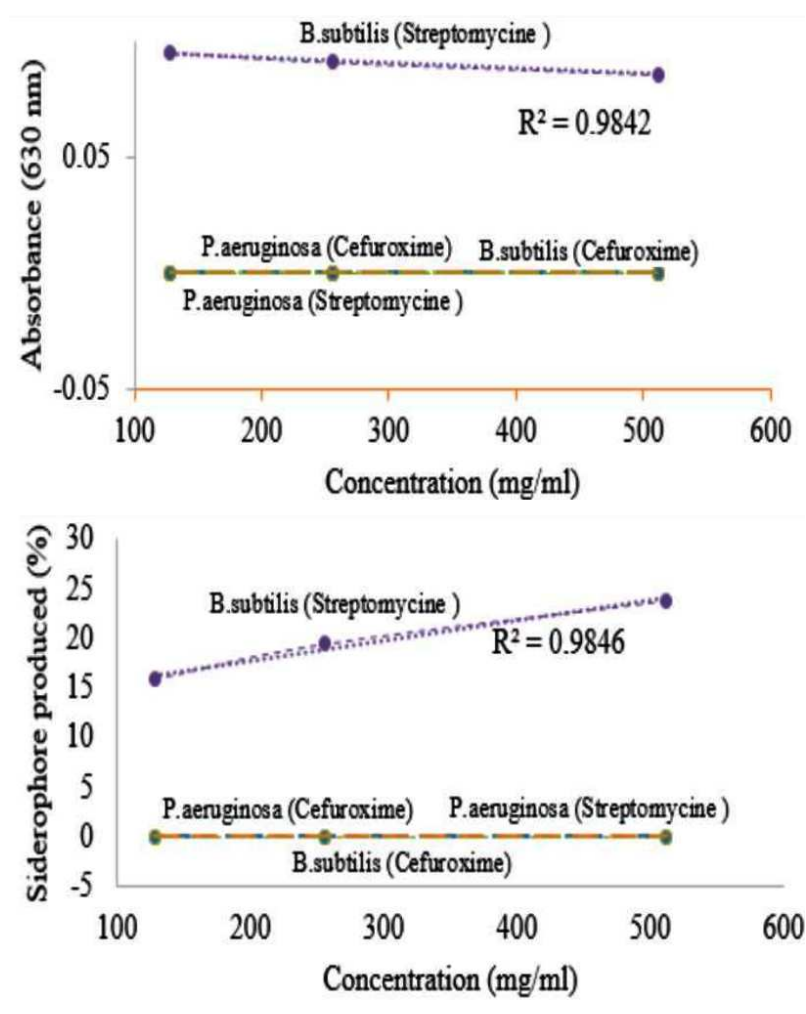

Fig. 2. Effect of cefuroxime and streptomycine on siderophore production in succinate medium by P.aeruginosa and B. subtilis.

\section{Conclusions}

In recent years, siderophores have attracted much attention due to appearance of different application areas. Because siderophores have the ability to bind a variety of metals in addition to iron, they have gained importance in various fields. Siderophores can be used as biocontrols, biosensors, bioremediation and chelation agents. The present study concludes that in the diesel oil contaminated soils $P$. aeruginosa and $B$. subtilis, producing siderophores, improve the plant growth and have antibacterial activity against the human clinical pathogens.

\section{References}

[1] J.M. Vraspir, A. Butler, Ann. Rev. Mar. Sci. 1, 43 (2009).

[2] R.Z. Sayyed, M.D. Badgujar, H.M. Sonawane, M.M. Mhaske, S.B. Chincholkar, Indian J. Biotech. 4, 484 (2005).

[3] A. Braud, V. Geoffroy, F. Hoegy, G.L.A. Mislin, I.J. Schalk, Environ. Microbiol. Rep. 2, 419 (2010).

[4] T. Gaonkar, S. Bhosle, Chemosphere 93, 1835 (2013).

[5] M. Rajkumar, N. Ae, M.N.V. Prasad, H. Freitas, Trends Biotechnol. 28, 142 (2010).

[6] B. Schwyn, J.B. Neiland, Anal. Biochem. 160, 47 (1987).

[7] J.M. Meyer, M.A. Abdallah, J. Gen. Microbiol. 107, 319 (1978).

[8] R.Z. Sayyed, P. Patel, Indian J. Microbiol. 51, 266 (2011).

[9] A. Nair, A.A. Juwarkar, S.K. Sing, Water Air Soil Pollut. 180, 199 (2007).

[10] D. Rachid, A. Bensoltane, African J. Biotechnol. 4, 697 (2005).

[11] B.K. Filali, J. Taoufik, Y. Zeroual, F.Z. Dzairi, M. Talbi, M. Belaghen, Curr. Microbiol. 41, 151 (2000).

[12] M. Rajkumar, N Ae, H. Freitas, Chemosphere 77 , 153 (2009).

[13] M.B. Sulochana, S.Y. Jayachandra, S.K.A. Kumar, A. Dayanand, J. Basic Microbiol. 54, 418 (2014).

[14] M. Radhakrishnan, K.J. Samshath, R. Balagurunathan, Curr. World Environ. 9, 990 (2014). 